\title{
The effect of zinc deficiency on wool growth and skin and wool follicle histology of male Merino lambs
}

\author{
BY C. L. WHITE ${ }^{1}$, G. B. MARTIN ${ }^{1,2}$, P. I. HYND A AND R. E. CHAPMAN ${ }^{4}$ \\ ${ }^{1}$ CSIRO Division of Animal Production, Private Bag, PO, Wembley, Western Australia 6014 \\ ${ }^{2}$ School of Agriculture (Animal Science), The University of Western Australia, Nedlands, \\ Western Australia 6009 \\ ${ }^{3}$ Department of Animal Sciences, Waite Research Institute, University of Adelaide, Glen Osmond, \\ South Australia 5064 \\ ${ }^{4}$ CSIRO Division of Animal Production, PO Box 239, Blacktown, NSW 2148, Australia
}

(Received 7 December 1992 - Revised 19 March 1993 - Accepted 27 April 1993)

\begin{abstract}
The aims of this work were to quantify the requirements of $\mathrm{Zn}$ for wool growth in growing male Merino lambs, and to describe the histological lesions of $\mathrm{Zn}$ deficiency in skin and wool follicles. Four groups of male Merino lambs $(n 4)$ weighing $22 \mathrm{~kg}$ were fed ad lib. for $96 \mathrm{~d}$ on diets that contained 4 (basal diet), 10,17 or $27 \mathrm{mg} \mathrm{Zn} / \mathbf{k g}$. Sheep in a fifth group were fed on the diet containing $27 \mathrm{mg} \mathrm{Zn/kg}$, but were pair-fed to sheep on the $4 \mathrm{mg} \mathrm{Zn/kg} \mathrm{diet.} \mathrm{Zn}$ was added to the basal diet as $\mathrm{ZnSO}_{4}$ to give the respective treatment concentrations. Sheep fed on the diet containing $4 \mathrm{mg} \mathrm{Zn} / \mathrm{kg}$ showed clinical signs of $\mathrm{Zn}$ deficiency and lower feed intakes and wool growth than sheep in the other groups. Their wool fibres were improperly keratinized and the wool follicles contained a higher proportion of apoptotic bodies than other groups. There was no evidence of parakeratosis and the rate of bulb-cell production was not affected. Sheep from other groups showed no clinical signs of $\mathrm{Zn}$ deficiency, and mean feed intakes and growth rates did not differ significantly between sheep fed on diets containing 10,17 or $27 \mathrm{mg} \mathrm{Zn/kg}$. However, wool growth was reduced in sheep fed on the diet containing $10 \mathrm{mg} \mathrm{Zn} / \mathrm{kg}$ compared with those fed on diets containing 17 or $27 \mathrm{mg} / \mathrm{kg}$. The mean concentration of $\mathrm{Zn}$ in the plasma at which wool growth was $90 \%$ of maximum was $0.5 \mathrm{mg} / \mathrm{l}$. The equivalent value for the diet was $12 \mathrm{mg} / \mathrm{kg}$, with $95 \%$ confidence intervals of 8 to $16 \mathrm{mg} / \mathrm{kg}$. The results suggest that $\mathrm{Zn}$ deficiency reduces wool growth through a specific mechanism, perhaps involving impaired protein synthesis.
\end{abstract}

Zinc: Wool: Skin: Sheep

Immature Merino wethers grazing spring pastures have a net $\mathrm{Zn}$ requirement of approximately $8 \mathrm{mg} / \mathrm{d}$ (Standing Committee on Agriculture, 1990). Of this, between 20 and $30 \%$ is incorporated into wool, assuming an average $\mathrm{Zn}$ concentration in clean wool of $110 \mathrm{mg} / \mathrm{kg}$ and a clean wool growth rate of $20 \mathrm{~g} / \mathrm{d}$ (Standing Committee on Agriculture, 1990). This deposition in wool represents a significant irreversible loss of $\mathrm{Zn}$ available for body tissues.

A severe dietary $\mathrm{Zn}$ deficiency (less than $3 \mathrm{mg} \mathrm{Zn} / \mathrm{kg}$ diet) causes cessation of wool growth in sheep (Ott et al. 1964, 1965; Mills et al. 1967; Underwood \& Somers, 1969; Masters et al. 1985), yet the minimum requirement of $\mathrm{Zn}$ for wool growth has not been established. Masters (1984) showed that Merino wethers fed on a diet containing $8.8 \mathrm{mg} \mathrm{Zn} / \mathrm{kg}$ grew less wool than sheep fed on diets containing $26.5 \mathrm{mg} \mathrm{Zn} / \mathrm{kg}$. In contrast, Lush \& Hynd (1988) were unable to show any differences in wool growth between Merino wethers fed diets containing 10 or $27 \mathrm{mg} \mathrm{Zn/kg}$.

It is of practical importance to know how much $\mathrm{Zn}$ is required for normal wool 
production because dry summer pastures grazed by sheep in parts of Australia contain low concentrations of $\mathrm{Zn}$ (below $20 \mathrm{mg} / \mathrm{kg}$ ) for several months (Masters \& Somers, 1980; White et al. 1991). Reproductive and growth responses to $\mathrm{Zn}$ supplements have been reported in sheep under natural grazing conditions (Egan, 1972; Masters \& Fels, 1980), indicating that low concentrations of $\mathrm{Zn}$ in pasture can restrict animal productivity.

The aims of this work were to quantify the requirements of $\mathrm{Zn}$ for wool growth in growing Merino ram lambs, and to describe the histological lesions of $\mathrm{Zn}$ deficiency in skin and wool follicles. The effects of $\mathrm{Zn}$ deficiency on reproductive endocrinology and testicular growth have been reported elsewhere (Martin \& White, 1992).

\section{MATERIALS AND METHODS \\ Animals and treatments}

Twenty 16-week-old male Merino lambs, weighing on average $22 \mathrm{~kg}$ at the start of treatment, were allocated to five treatment groups each of four sheep. The first four treatments consisted of feeding ad lib. on diets ranging in $\mathrm{Zn}$ concentration from deficient to adequate: 4 (deficient), 10, 17 and $27 \mathrm{mg} / \mathrm{kg}$ (ad lib. control). The fifth treatment (pairfed control) consisted of feeding each of the sheep on an amount of the $27 \mathrm{mg} \mathrm{Zn} / \mathrm{kg}$ diet equal to that eaten by its $\mathrm{Zn}$-deficient pair $(4 \mathrm{mg} \mathrm{Zn} / \mathrm{kg}$ ) the previous day. This technique offered the means of controlling for effects of reduced feed intake in the deficient sheep. The composition of the basal diet is shown in Table $1 . \mathrm{ZnSO}_{4} .7 \mathrm{H}_{2} \mathrm{O}$ was added to the basal diet at $26.5,57.5$ and $115 \mathrm{mg} / \mathrm{kg}$ to give the desired treatment concentrations of $\mathrm{Zn}$. The experimental period lasted $96 \mathrm{~d}$ and was preceded by a 3-week adjustment period when all sheep were given the control diet containing $27 \mathrm{mg} \mathrm{Zn/kg}$.

Sheep were kept in individual pens made of plastic-coated iron railings (not galvanized) and with slatted wooden floors. Feed bins were made of fibreglass and plastic, and the deionized watering nipples of stainless steel. The experiment was carried out under the Code of Practice for the Care and Use of Animals for Experimental Purposes (National Health and Medical Research Council, 1985).

\section{Wool sampling and analysis}

A $100 \mathrm{~cm}^{2}$ area of skin on the right mid-side of the sheep was marked with an indelible pen on day 5 of treatment and closely clipped using model A 5 Oster small-animal clippers fitted with size 40 cutters. Wool was harvested from the patch at subsequent 14-d intervals. Wool samples were equilibrated to $12 \%$ moisture and weighed. Samples from day 89 were analysed for wax, suint and yield.

Wool samples for $\mathrm{Zn}$ and $\mathrm{Cu}$ analysis were cleaned using a modified method of Hemsley $\&$ Marshall (1983). Samples of approximately $0.8 \mathrm{~g}$ were weighed and placed into weighed glass syringes, dried for $30 \mathrm{~min}$ in a $90^{\circ}$ chamber containing $\mathrm{N}_{2}$, and the syringe plus wool was then reweighed. Wax was extracted using five $30 \mathrm{~s}$ washes in $2 \mathrm{ml}$ Shell X2 solvent/g wool. Excess solvent was removed under compressed air and the wool and syringe were dried under $\mathrm{N}_{2}$ at $90^{\circ}$ for $30 \mathrm{~min}$ and reweighed to give a measurement of wax content. Suint was then extracted by washing the wool twice with $30 \mathrm{ml}$ distilled water at $60^{\circ}$. The syringe plus wool was dried overnight in a $90^{\circ}$ oven, cooled in a desiccator and weighed before digestion in acid and analysis for $\mathrm{Zn}$ and $\mathrm{Cu}$.

\section{Measurement of mitotic rate}

Colchicine-treated skin biopsy samples were taken on day 83 of treatment from the upper mid-side of the sheep using the method of Hynd et al. (1986). Bulbs (300 to 600/sample) were scored for mitotic figures for each sample. All bulbs present in a section were counted. 
Table 1. Composition $(\mathrm{g} / \mathrm{kg})$ of the basal diet

\begin{tabular}{|c|c|}
\hline \multicolumn{2}{|l|}{ Ingredient } \\
\hline Oat straw* & 400 \\
\hline Wheat starch & 250 \\
\hline Sucrose & 150 \\
\hline Spray-dried egg white & 75 \\
\hline Vegetable oil (mixed, soya-bean based) & 20 \\
\hline Urea* & 20 \\
\hline $\begin{array}{l}\text { Vitamins A and vitamin } D_{3}(150 \mathrm{mg} / \mathrm{g} \text { and } 2.5 \mathrm{mg} / \mathrm{g} \\
\text { respectively: Rovimix) }\end{array}$ & $0 \cdot 01$ \\
\hline Vitamin E (500 mg $\alpha$-tocopherol/g; Rovimix) & $0 \cdot 1$ \\
\hline Tetrapotassium pyrophosphate* & 30 \\
\hline $\mathrm{CaCO}_{3}^{*}$ & $25 \cdot 9$ \\
\hline $\mathrm{CaSO}_{4}(\mathrm{Gypsum})^{*}$ & $6 \cdot 2$ \\
\hline $\mathrm{MgCO}_{3}(\text { light })^{*}$ & $2 \cdot 15$ \\
\hline $\mathrm{KOH}^{*}$ & $11 \cdot 9$ \\
\hline $\mathrm{NaOH}^{*}$ & $8 \cdot 4$ \\
\hline Trace element premix $\dagger$ & $0 \cdot 265$ \\
\hline
\end{tabular}

* The oat straw was treated with alkali, macro-elements and urea to make alkali-treated straw. To each $100 \mathrm{~kg}$ dry straw was added a solution containing 13.31 distilled water, $2.86 \mathrm{~kg} \mathrm{KOH}$ and $2.0 \mathrm{~kg} \mathrm{NaOH}$. The macrominerals and urea were then added and the 'alkalage' allowed to sit in bags for at least 2 weeks before mixing with the remaining dietary ingredients. The basal diet contained (by analysis, $\mathrm{mg} / \mathrm{kg} \mathrm{DM}$ (SE)): $\mathrm{Zn} 3.9$ (1), $\mathrm{Cu} 7.0$ (1.4), Fe 290, Mo 1.7 (0.2). The untreated straw contained $(\mathrm{g} / \mathrm{kg}): \mathrm{S} 0 \cdot 8, \mathrm{~N} 5 \cdot 1, \mathrm{Zn} 3 \cdot 3 \mathrm{mg}$.

$\dagger$ The trace-element premix contained $(\mathrm{g} / \mathrm{kg}): \mathrm{Fe}_{2}\left(\mathrm{SO}_{4}\right)_{3} .9 \mathrm{H}_{2} \mathrm{O} 568, \mathrm{MnSO}_{4} \cdot \mathrm{H}_{2} \mathrm{O} 230, \mathrm{CuSO}_{4} \cdot 5 \mathrm{H}_{2} \mathrm{O} 73 \cdot 3$, $\mathrm{Na}_{2} \mathrm{MoO}_{4} \cdot 2 \mathrm{H}_{2} \mathrm{O} 19 \cdot 0, \mathrm{CoCl}_{2}, 6 \mathrm{H}_{2} \mathrm{O} 1.51, \mathrm{Na}_{2} \mathrm{SeO}_{3} 2.49, \mathrm{KI} \quad 0.49, \mathrm{Na}_{2} \mathrm{HAsO}_{4} .7 \mathrm{H}_{2} \mathrm{O} 1.55, \mathrm{NH}_{4} \mathrm{VO}_{3} \quad 0.86$, $\mathrm{Na}_{2} \mathrm{Cr}_{2} \mathrm{O}_{3} .2 \mathrm{H}_{2} \mathrm{O} 1 \cdot 09, \mathrm{Na}_{2} \mathrm{~B}_{4} \mathrm{O}_{7} .10 \mathrm{H}_{2} \mathrm{O} 100, \mathrm{NiSO}_{4} \cdot 6 \mathrm{H}_{2} \mathrm{O} 1 \cdot 70$. For each $470 \mathrm{~kg}$ (dry matter) batch of feed, $124 \mathrm{~g}$ of the trace-element premix was dissolved in $500 \mathrm{ml}$ concentrated $\mathrm{HCl}$ and made up to $5 \mathrm{l}$ in distilled water. The solution was left to stand overnight and added to the feed during mixing.

The data represent the mean number of cells undergoing mitosis in the $2 \mathrm{~h}$ period of colchicine arrest in the average follicle bulb section.

\section{Histological examination of skin}

Skin samples were taken from the upper mid-side region with a $10 \mathrm{~mm}$ diameter trephine following subcutaneous administration of $0.5 \mathrm{ml}$ local anaesthetic (xylocaine) on days 0,26 , 54 and 83 of treatment. The samples were fixed in buffered formalin $\left(3.97 \mathrm{~g} \mathrm{KH}_{2} \mathrm{PO}_{4}\right.$ and $7.97 \mathrm{~g} \mathrm{~K}_{2} \mathrm{HPO}_{4} / 100 \mathrm{ml}$ formalin $(400 \mathrm{ml} \mathrm{HCHO} / \mathrm{l})$ made to 11 in distilled water) embedded in paraffin, sectioned at $8 \mu \mathrm{m}$ thickness and stained with haematoxylin, eosin and picric acid (Carter \& Clarke, 1957).

\section{Trace element determination}

The $\mathrm{Zn}$ and $\mathrm{Cu}$ concentrations of feed and wool were determined using atomic absorption spectroscopy (AAS) on $0.5 \mathrm{~g}$ samples digested in a mixture of $7 \mathrm{ml} \mathrm{HNO}$ ( $16 \mathrm{~mol} / \mathrm{l}), 0.5 \mathrm{ml}$ $\mathrm{H}_{2} \mathrm{SO}_{4}(18 \mathrm{~mol} / \mathrm{l})$ and $0.5 \mathrm{ml} \mathrm{HClO}_{4}(12 \mathrm{~mol} / \mathrm{l})$. Concentrations of metal are expressed on a dry matter basis. Plasma was treated with $10 \%$ trichloroacetic acid (w/v), centrifuged for $15 \mathrm{~min}$ at $1500 \mathrm{~g}$ and the supernatant fraction analysed for $\mathrm{Zn}$ using AAS.

\section{Statistical methods}

Data were analysed by analysis of variance using the micro-computer program Systat (Systat Inc., Evanston, IL, USA). Repeated measures analysis of variance was performed where appropriate. Between-treatment comparisons were made using least significant 
differences (LSD; Steel \& Torrie, 1980). Non-linear Mitscherlich equations were fitted to mean values for the relationship between dietary and plasma $\mathrm{Zn}$ concentrations and wool growth.

\section{RESULTS}

Wool growth, live weight gain and feed intake

Wool growth was rapidly and severely reduced in sheep fed on the $4 \mathrm{mg} \mathrm{Zn} / \mathrm{kg}$ diet, and marginally reduced in those fed on the $10 \mathrm{mg} \mathrm{Zn} / \mathrm{kg}$ diet compared with those fed ad lib. on the 17 or $27 \mathrm{mg} \mathrm{Zn/kg} \mathrm{diets} \mathrm{(Fig.} \mathrm{1).} \mathrm{Repeated} \mathrm{measures} \mathrm{analysis} \mathrm{of} \mathrm{variance} \mathrm{showed}$ significant effects of treatment $(P<0.001)$ and time $(P<0.001)$ and a significant time $\times$ treatment interaction $(P<0.001)$. Sheep given the $10 \mathrm{mg} \mathrm{Zn} / \mathrm{kg}$ diet grew significantly less wool than those given the $17 \mathrm{mg} \mathrm{Zn} / \mathrm{kg}$ diet, but only on days 61 and 75 of sampling $(P<0.05)$. Pair-fed control sheep grew significantly more wool than $\mathrm{Zn}$-deficient sheep at all times after the first sampling at day 19, but less wool than sheep given the 17 or $27 \mathrm{mg} \mathrm{Zn} / \mathrm{kg}$ diet ad lib. $(P<0.05)$. Pair-fed sheep grew less wool than those given $10 \mathrm{mg} \mathrm{Zn} / \mathrm{kg}$ diet, but only on sampling days 75 and $89(P<0 \cdot 05)$.

Body growth virtually ceased in both $\mathrm{Zn}$-deficient and pair-fed sheep (Fig. 1), and growth rate for sheep in these two groups was significantly lower than for other groups (repeated measures analysis of variance, $P<0.001$ ). However, growth was not significantly different between sheep fed ad lib. on diets containing 10, 17 or $27 \mathrm{mg} \mathrm{Zn/kg} \mathrm{(Fig.} \mathrm{1).} \mathrm{Daily}$ feed intakes for the five treatment groups were (mean (SE), g); 693 (72), 1316 (59), 1411 (51), 1532 (97) and 703 (67) respectively. Only the Zn-deficient and pair-fed groups had significantly reduced feed intakes and there was no significant difference between intakes for sheep fed ad lib. on the 10,17 or $27 \mathrm{mg} \mathrm{Zn} / \mathrm{kg}$ diets.

Clean wool growth on day 89 of treatment was reduced only when dietary $\mathrm{Zn}$ concentration fell below $17 \mathrm{mg} / \mathrm{kg}$, whereas plasma $\mathrm{Zn}$ concentration was reduced at all concentrations of dietary $\mathrm{Zn}$ below $27 \mathrm{mg} / \mathrm{kg}$ (Fig. 2). Pair-fed sheep had mean plasma $\mathrm{Zn}$ concentrations that were not significantly different from ad lib.-fed sheep on diets containing 17 or $27 \mathrm{mg} \mathrm{Zn/kg}$.

Estimates of the concentrations of $\mathrm{Zn}$ in the diet at which wool growth was $90 \%$ of maximum ( $90 \%$ critical value; Ulrich, 1952) were obtained by fitting a Mitscherlich curve (Fig. 2). The critical value for wool growth was $12 \mathrm{mg} \mathrm{Zn/kg}$ in the diet, corresponding to $0.5 \mathrm{mg} \mathrm{Zn/1} \mathrm{in} \mathrm{plasma.}$

\section{Wax and suint}

$\mathrm{Zn}$ deficiency increased the concentration of wax $(P=0.2)$ and suint $(P<0.01)$ in wool, and consequently decreased the yield $(P<0 \cdot 01$, Fig. 3). Composition and yield of wool from pair-fed control sheep were the same as from sheep fed ad lib. on the control diet. There were no significant differences in wax, suint or yield between the sheep fed on diets containing 10,17 or $27 \mathrm{mg} \mathrm{Zn/kg}$.

\section{Mitotic rate}

There was only a slight non-significant reduction in the mean number of mitoses per bulb section in the deficient sheep compared with other groups (ANOVA, $P>0.05$; Fig. 4). There was no significant linear relationship between mitotic rate and clean wool growth $\left(r^{2} 0 \cdot 21, n 20, P>0 \cdot 05\right)$.

Although mitotic rate was not decreased by $\mathrm{Zn}$ deficiency, there was a change in the pattern of mitosis within the bulb brought about by a change in bulb shape. The bulbs of $\mathrm{Zn}$-deficient sheep were more elongated and narrower, with metaphase nuclei apparent a large distance from the base of the bulb. It appeared that the germinative tissue of the bulb had been drawn upwards and inwards. 

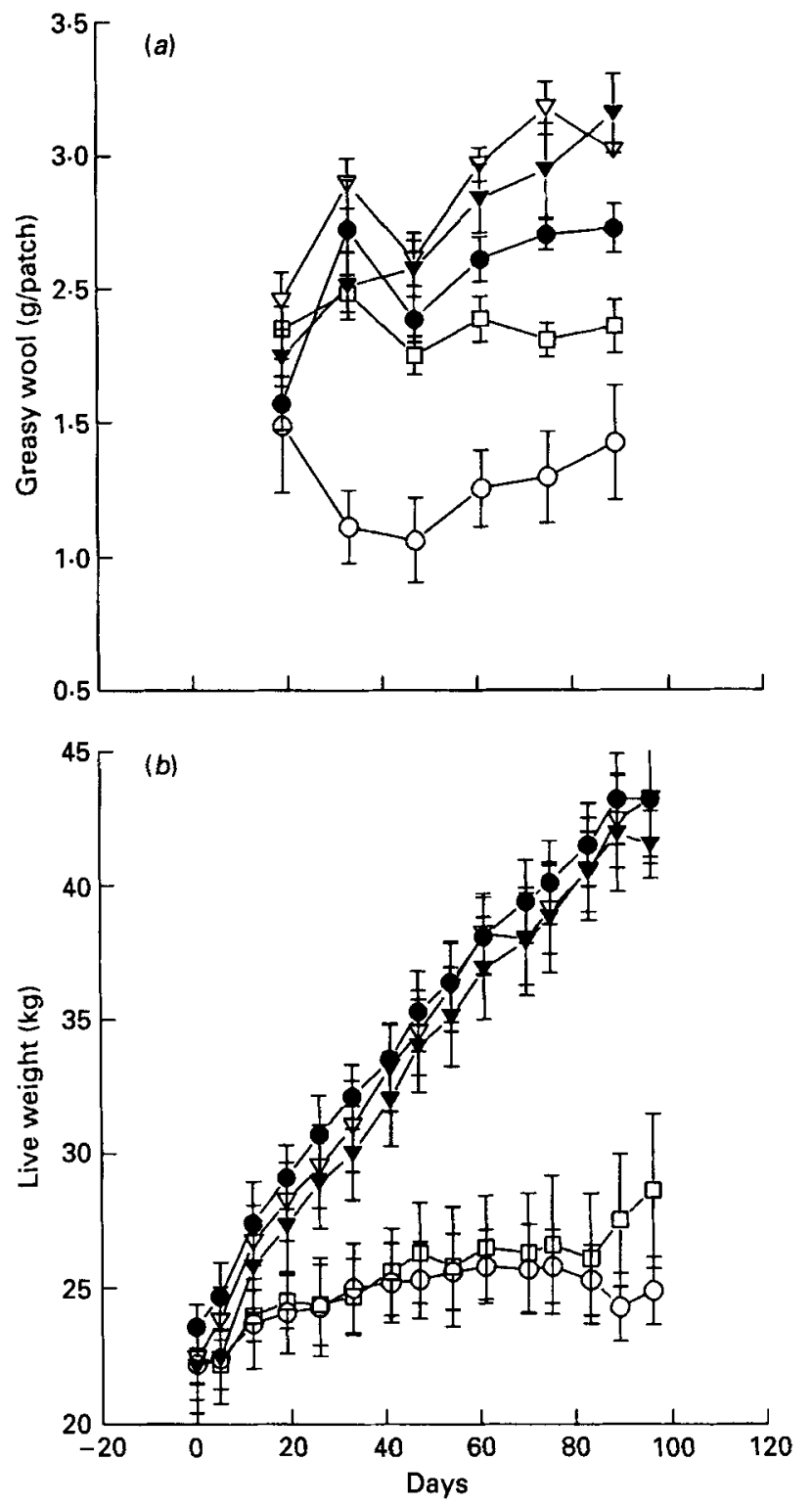

Fig. 1. The effect of dietary $\mathrm{Zn}$ on wool growth $(a)$ and live-weight gain $(b)$. Values are means with their standard errors for four sheep per group. Symbols represent dietary Zn treatments: $4 \bigcirc-0,100-0,17 \nabla-\nabla, 27$ (ad lib.) $\nabla-\nabla$ and 27 (pair-fed) $\mathrm{mg} \mathrm{Zn} / \mathrm{kg} \square-\square$.

\section{Skin histology}

Skin samples only from the Zn-deficient sheep showed evidence of histopathological changes. In the samples taken on days 26, 54 and 83 there were more apoptotic bodies (Kerr et al. 1972) in the $4 \mathrm{mg} \mathrm{Zn/kg}$ group than other groups (Fig. 5a).

Wool fibres from $\mathrm{Zn}$-deficient sheep were improperly keratinized as indicated by retained cell nuclei in the fibres (Fig. 5b). The partial keratinization also appeared to have proceeded more slowly in the samples taken on day 83 than at earlier times, as judged by longer 


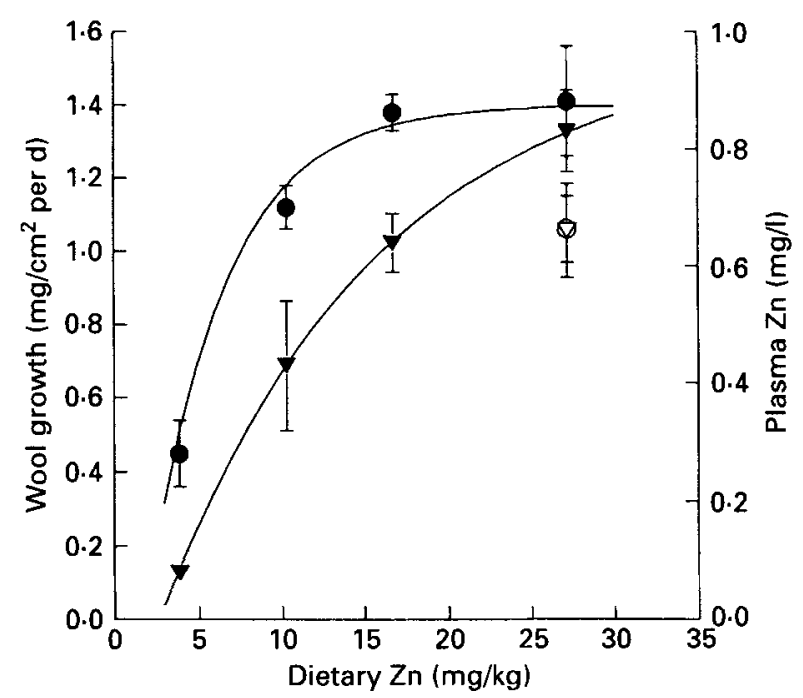

Fig. 2. The effect of dietary $\mathrm{Zn}$ concentration on clean wool growth (-) between days 75 and 89 of treatment, and concentration of $\mathrm{Zn}$ in plasma $(\boldsymbol{\nabla}-\boldsymbol{\nabla})$ at day 89 of sampling. Open symbols represent values for the pair-fed control group. Values are means with their standard errors for four sheep per group. The fitted curves are described by the Mitscherlich equations $Y=1.4-2 \cdot 1 \exp (-0.22 X)\left(r^{2} 0.99\right)$ for wool growth and $Y=$ $0.98-1.2 \exp (-0.076 X)\left(r^{2} 0.99\right)$ for plasma $\mathrm{Zn}$.

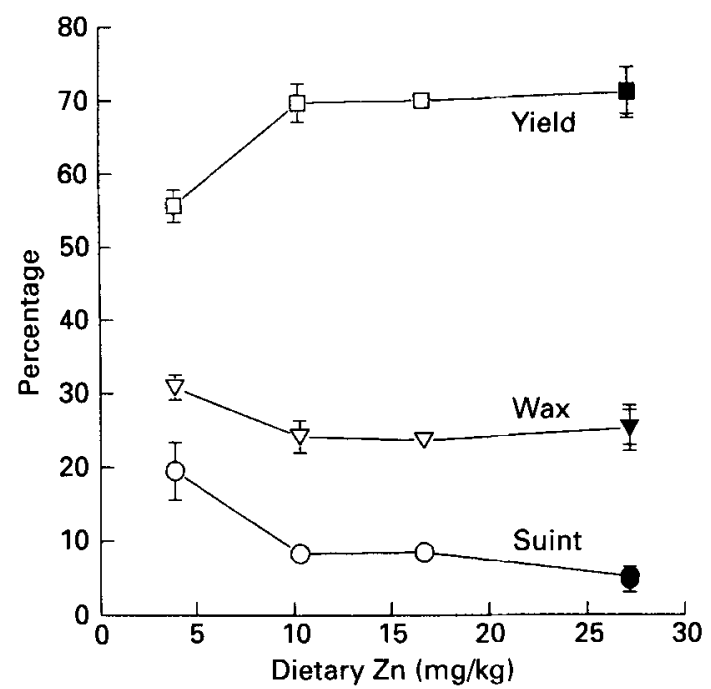

Fig. 3. The effect of dietary $\mathrm{Zn}$ concentration on yield $(\square-\square)$, wax $(\nabla-\nabla)$ and suint $(\mathrm{O}-\mathrm{O})$ of wool grown between days 75 and 89 of treatment. Closed symbols represent values for the pair-fed control group. Values are means with their standard errors for four sheep per group.

keratogenous zones in those follicles. A small percentage $(<5 \%)$ of fibres were distorted in the upper parts of the follicles and degraded within thickened outer root sheaths (Fig. 5c). This small percentage would account for the lack of any break in the wool of the Zndeficient group. There was no obvious sign of impaired keratinization of fibres in the control groups consuming $27 \mathrm{mg} \mathrm{Zn} / \mathrm{kg}$ in spite of the low $\mathrm{Cu}$ concentrations in the wool of this group (Fig. 6). 


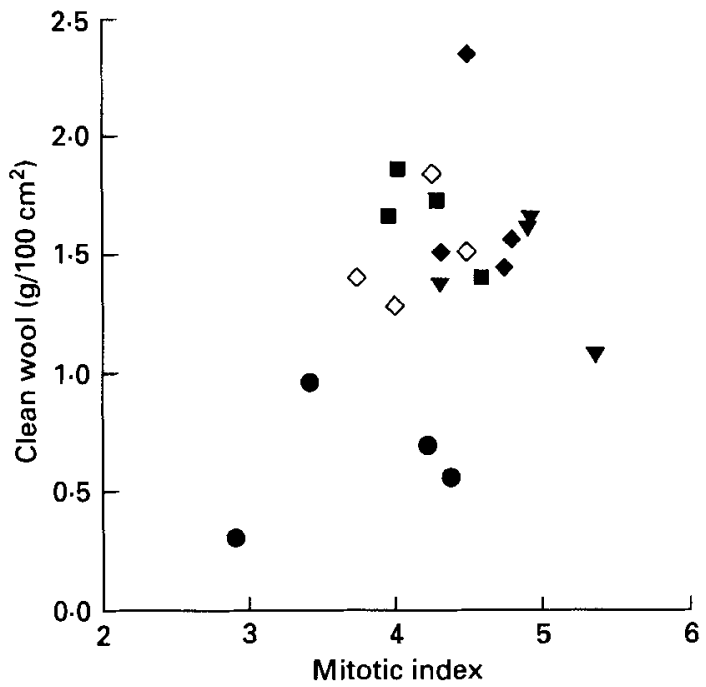

Fig. 4. The relationship between mitotic rate on day 83 and clean wool growth between days 75 and 89 of treatment. There was no significant linear relationship $(P>0.05)$. Each value represents a single sheep. Symbols represent treatments as follows: $4 \bullet, 10 \nabla, 17 \boldsymbol{\square}, 27$ (ad lib.) $\diamond$, and 27 (pair-fed) $\mathrm{mg} \mathrm{Zn/kg} \diamond$.
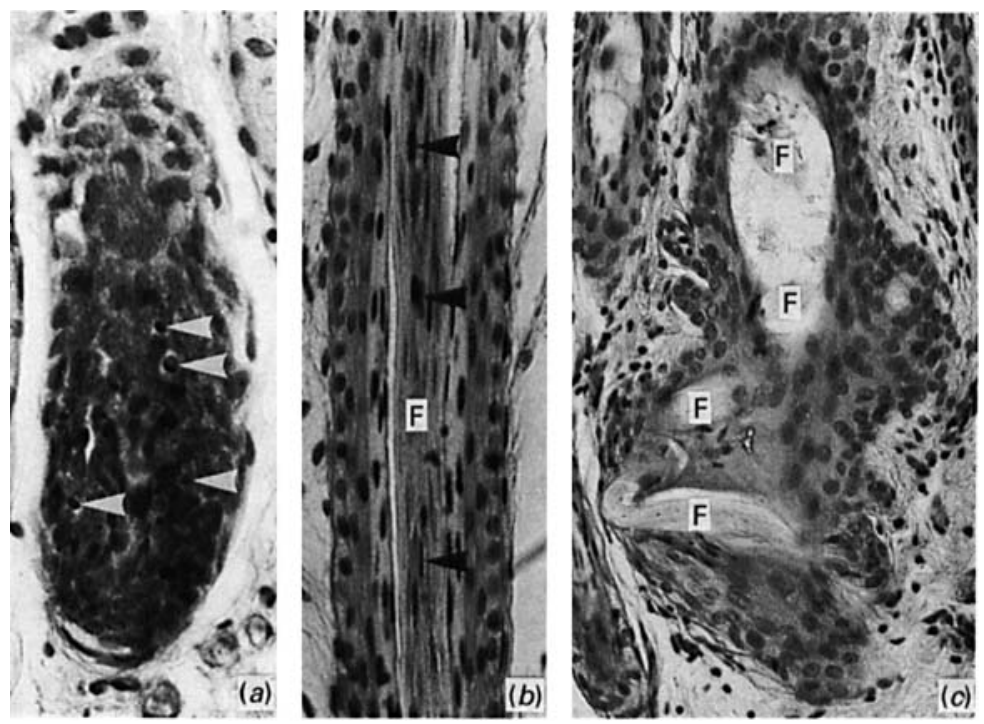

Fig. 5. Abnormal features present from day 26 onwards in skin samples from sheep fed on a Zn-deficient diet: (a) Apoptotic bodies (arrowheads) in follicle bulb. (b) Retained cell nuclei (arrowheads) in an improperly keratinized wool fibre (F). (c) A distorted and partly degraded wool fibre (F) in the distal part of a follicle. For details of procedures, see p. 427.

More follicles remained immature longer in the $\mathrm{Zn}$-deficient and $10 \mathrm{mg} \mathrm{Zn} / \mathrm{kg}$ diet groups; $9 \%$ compared with $4 \%$ in other groups at day 83 . Histological examination of cortical cells from $\mathrm{Zn}$-deficient and pair-fed sheep showed that $\mathrm{Zn}$ deficiency caused a significant reduction in cell width $(4.9$ (SE 0.1) v. 5.6 (SE 0.2) $\mu \mathrm{m} ; P<0.05$ ) and cell volume (546 (SE 39) v. 775 (SE 48) $\mu \mathrm{m}^{3} ; \quad P<0.01$ ) with no significant change in cell length 


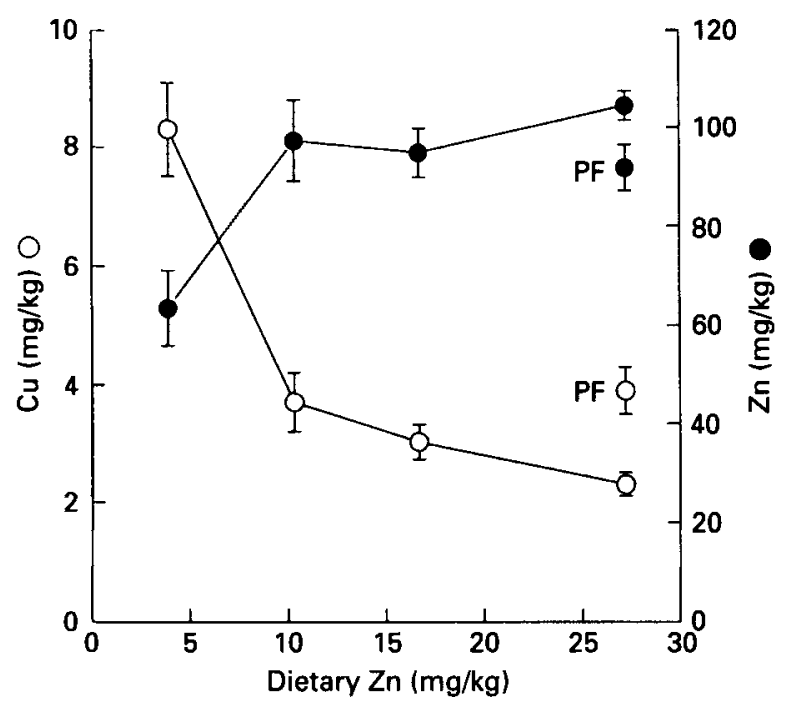

Fig. 6. The effect of dietary $\mathrm{Zn}$ concentration on the $\mathrm{Zn}\left(\mathrm{O}^{-} \mathrm{O}\right)$ and $\mathrm{Cu}(\mathrm{O}-\mathrm{O})$ concentrations in clean wool on day 89 of treatment. PF signifies values for the pair-fed control treatment. Values are means with their standard errors for four sheep per group. For details of treatments and procedures, see pp. 426-427.

(77 (SE 5) v. 86 (SE 2) $\mu \mathrm{m} ; P<0 \cdot 157$ ). The only other detected effect of $\mathrm{Zn}$ deficiency in the $\mathrm{Zn}$-deficient group was a slight tendency towards more stratum corneum on the epidermis in samples taken on day 83 . However, the epidermis could not be regarded as hyperkeratotic and there was no sign of parakeratosis in any of the samples.

The sizes of the sebaceous and sweat glands bore no relation to the amount of $\mathrm{Zn}$ ingested. Apart from slightly retarded maturation of follicles in the $10 \mathrm{mg} \mathrm{Zn} / \mathrm{kg}$ diet group, there were no histological differences between the $10 \mathrm{mg} \mathrm{Zn} / \mathrm{kg}$ diet and the 17 and $27 \mathrm{mg} \mathrm{Zn/kg}$ diet groups.

\section{Zinc and copper contents of wool}

The concentration of $\mathrm{Zn}$ in wool was only significantly reduced in the $\mathrm{Zn}$-deficient group compared with other groups $(P<0.01 ;$ Fig. 6$)$. However, the concentration of $\mathrm{Cu}$ in wool showed a progressive decline with increasing $\mathrm{Zn}$ concentration in the diet $(P<0.01)$. Pairfed sheep receiving the $27 \mathrm{mg} \mathrm{Zn/kg}$ diet had a higher mean concentration of $\mathrm{Cu}$ than $\mathrm{ad}$ lib.-fed control sheep $(P<0.05)$ and this value was similar to that for the 10 and $17 \mathrm{mg} \mathrm{Zn/kg} \mathrm{groups.}$

\section{DISCUSSION}

Using the concept of critical value as described by Ulrich (1952), the results show that the concentrations of $\mathrm{Zn}$ in the diet and plasma at which wool growth was $90 \%$ of maximum were $12 \mathrm{mg} / \mathrm{kg}$ and $0.5 \mathrm{mg} / \mathrm{l}$ for a mean rate of wool growth of $1.4 \mathrm{mg} / \mathrm{cm}^{2}$ per d. If the coefficient of variation of $\mathrm{Zn}$ requirements is the same as that for voluntary feed intake (7-16\%; Minson, 1990) then the population range (mean $\pm 2 \mathrm{SD}$ ) over which $\mathrm{Zn}$ intakes can be considered marginal for wool growth in Merino sheep extends from approximately 8 to $16 \mathrm{mg} / \mathrm{kg}$ for the diet and 0.34 to $0.66 \mathrm{mg} / 1$ for plasma.

A critical value represents a minimum concentration of a nutrient under conditions where other nutrients are non-limiting. The failure of Lush \& Hynd (1988) to observe a reduction in wool growth in Merino wethers fed on diets containing $10 \mathrm{mg} \mathrm{Zn} / \mathrm{kg}$, 
compared with those of $27 \mathrm{mg} / \mathrm{kg}$ diet and above, could be explained by the fact that the rate of wool growth in their $\mathrm{Zn}$-adequate sheep was low $\left(0.7 \mathrm{mg} / \mathrm{cm}^{2}\right.$ per d). Evidence to support the effects of diet quality on $\mathrm{Zn}$ requirements for wool growth comes from the work of Masters (1984), who showed that increasing dietary $\mathrm{Zn}$ from 4.8 to $26.5 \mathrm{mg} / \mathrm{kg}$ only increased wool growth when dietary $\mathrm{N}$ concentration was increased from 10 to $30 \mathrm{~g} / \mathrm{kg}$, causing wool growth rate to increase from 0.74 to $1.3 \mathrm{mg} / \mathrm{cm}^{2}$ per d. Under conditions where wool growth is below the genetic potential the concentration of $\mathrm{Zn}$ in plasma may prove to be a more useful indicator of the adequacy of $\mathrm{Zn}$ supply than dietary $\mathrm{Zn}$ concentration. Thus, a plasma $\mathrm{Zn}$ concentration below $0.5 \mathrm{mg} / 1$ may indicate an inadequate supply of $\mathrm{Zn}$ for wool growth, even when feed quality and wool growth rate are low.

The maximum rate of wool growth of $1.4 \mathrm{mg} / \mathrm{cm}^{2}$ per $\mathrm{d}$ in the current experiment corresponds to a total body production of $15.4 \mathrm{~g}$ clean wool/d (Bennett, 1973), an amount below the maximum rate of about $20 \mathrm{~g} / \mathrm{d}$ reported for Merinos at pasture (Hogan et al. 1979). There is no appreciable photoperiod effect on wool growth in Merinos (Nagorcka, 1979) and the seasonal variation in clean wool growth of about 4 to $20 \mathrm{~g} / \mathrm{d}$ is determined largely by diet quality. It is, therefore, possible that the higher wool growth in sheep at pasture compared with that in this experiment would necessitate a mean requirement of dietary $\mathrm{Zn}$ concentration of $16 \mathrm{mg} / \mathrm{kg}$ if $\mathrm{Zn}$ requirement is linearly proportional to wool growth. It is considered likely that these results can be applied to sheep grazing natural herbage because tracer studies with ruminants have shown that the absorption and retention of inorganic forms of $\mathrm{Zn}$ are largely indistinguishable from intrinsically labelled plant material (Neathery et al. 1972; Bedi \& Chesters, 1982) and Zn from forage diets is highly available to sheep (Suttle et al. 1982).

Histological lesions in the skin and wool follicle of sheep fed on the diet containing $4 \mathrm{mg} \mathrm{Zn} / \mathrm{kg}$ were similar to, but less extensive than, those reported in pre-ruminant lambs fed on a milk diet containing $3 \mathrm{mg} \mathrm{Zn/} \mathrm{kg}$ dry matter (Masters et al. 1985). In the current experiment skin from the $\mathrm{Zn}$-deficient sheep contained apoptotic bodies in follicle bulbs, impaired keratinization of fibres with retained cell nuclei and fibre distortion in the distal parts of some follicles.

The finding that $\mathrm{Zn}$ deficiency had little effect on mitotic activity per follicle bulb is surprising in the light of evidence that $\mathrm{Zn}$ is required for several enzymes controlling events during cell division and gene expression (Vallee \& Falchuk, 1981). A decrease in wool output per unit area of skin with no change in the rate of wool production per bulb would require a decrease in follicle density or a decrease in cortical cell size or both. The $30 \%$ reduction in cortical cell size of $\mathrm{Zn}$-deficient sheep compared with pair-fed sheep supports the contention that the keratinization (protein synthetic) process is more sensitive to reduced $\mathrm{Zn}$ supply than is cell division.

Defective keratinization is not specific to $\mathrm{Zn}$ deficiency and occurs in sheep fed on whole grain supplemented with methionine (Chapman \& Reis, 1978), in preruminant folatedeficient lambs (Chapman, 1989) and in lambs fed on diets deficient in lysine (Chapman et al. 1983). Whether $\mathrm{Zn}$ is required for the structural integrity of the wool keratin proteins or whether it is required as a component of an enzyme for wool protein synthesis cannot be determined from this study. The $\mathrm{Zn}$ content of wool did not reflect $\mathrm{Zn}$ intake since there was no correlation between the concentration of $\mathrm{Zn}$ in the wool and the concentrations of $\mathrm{Zn}$ in either the diet or plasma when levels of dietary $\mathrm{Zn}$ were between 10 and $27 \mathrm{mg} / \mathrm{kg}$. Only when $\mathrm{Zn}$ intakes became sufficiently low to cause major histological changes to the wool fibre did the concentration of $\mathrm{Zn}$ in wool decline. The fact that $\mathrm{Cu}$ concentration was increased significantly in wool only from sheep fed on the diet containing $4 \mathrm{mg} \mathrm{Zn} / \mathrm{kg}$ further indicates a major physicochemical change in the wool fibre brought about by $\mathrm{Zn}$ deficiency. 
In summary, the results show that for a wool growth rate of $1.4 \mathrm{mg} / \mathrm{cm}^{2}$ per $\mathrm{d}$ the $90 \%$ critical concentration of dietary $\mathrm{Zn}$ for wool growth was about $12 \mathrm{mg} / \mathrm{kg}$. The equivalent concentration in plasma was $0.5 \mathrm{mg} / \mathrm{l}$. A diet of $10 \mathrm{mg} \mathrm{Zn} / \mathrm{kg}$ was adequate to prevent clinical signs of $\mathrm{Zn}$ deficiency but not to maintain a maximum rate of wool growth. A diet of $4 \mathrm{mg} \mathrm{Zn} / \mathrm{kg}$ produced clinical signs of $\mathrm{Zn}$ deficiency and markedly reduced the rate of wool growth. This reduction was associated with an impaired keratinization of the wool fibre that was not due to a reduced rate of mitosis in the bulb cells. The results suggest that $\mathrm{Zn}$ deficiency reduces wool growth through a specific mechanism, perhaps involving protein synthesis. It was not due simply to a generalized effect of $\mathrm{Zn}$ deficiency on appetite or rate of cell division.

This work was supported by grants from the joint CSIRO-University of Western Australia Research Fund, the Australian Research Council, the Australian Wool Corporation and the Australian Pastoral Research Trust. The authors wish to thank the following people for their technical assistance: M. Barnes, J. Briegel, S. Roe and C. Wilson.

\section{REFERENCES}

Bedi, S. P. S. \& Chesters, J. K. (1982). Assessment of the availability of dietary copper and zinc to sheep using radioisotopes. Nutrition Reports International 25, 277-283.

Bennet, J. W. (1973). Regional body surface area of sheep. Journal of Agricultural Science, Cambridge 81, 429-432.

Carter, H. B. \& Clarke, W. J. (1957). The hair follicle group and skin follicle population of Australian Merino sheep. Australian Journal of Agricultural Research 8, 91-108.

Chapman, R. E. (1989). Follicular malfunctions and resultant effects on wool fibres. In The Biology of Wool and Hair, pp. 243-256 [G. E. Rogers, P. J. Reis, K. A. Ward and R. C. Marshall, editors]. London: Chapman and Hall.

Chapman, R. E., Colebrook, W. F. \& Black, J. L. (1983). Influence of dietary lysine content on wool follicle function in pre-ruminant lambs. Journal of Agricultural Science, Cambridge 101, 139-145.

Chapman R. E. \& Reis, P. J. (1978). Effects of abomasal supplements of methionine on the wool follicles and skin of wheat-fed sheep. Australian Journal of Biological Science 31, 161-172.

Egan, A. R. (1972). Reproductive responses to supplemental zinc and manganese in grazing Dorset Horn ewes. Australian Journal of Experimental Agriculture and Animal Husbandry 12, 131-135.

Hemsley, J. A. \& Marshall, J. T. A. (1983). A column extraction method for the estimation of wax and suint in raw wool. Wool Technology and Sheep Breeding 31, 158-163.

Hogan, J. P., Elliot, N. M. \& Hughes, A. D. (1979). Maximum wool growth rates expected from Australian Merino genotypes. In Physiological and Environmental Limitations to Wool Growth, pp. 43-59 [J. L. Black and P. J. Reis, editors]. Armidale: University of New England Publishing Unit.

Hynd, P. I., Schlink, A. C., Phillips, P. M. \& Scobie, D. R. (1986). Mitotic activity in cells of the wool follicle bulb. Australian Journal of Biological Science 39, 329-339.

Kerr, J. F. R., Wyllie, A. H. \& Currie, A. R. (1972). A poptosis: a basic biological phenomenon with wide-ranging implications in tissue kinetics. British Journal of Cancer 26, 239-257.

Lush, J. M. \& Hynd, P. I. (1988). The effect of zinc deficiency on wool growth. Proceedings of the Nutrition Society of Australia 13, 87.

Martin, G. M. \& White, C. L. (1992). Effects of dietary zinc deficiency on gonadotrophin secretion and testicular growth in young male sheep. Journal of Reproduction Fertility 96, 497-507.

Masters, D. G. (1984). Zinc in wool and the assessment of zinc nutrition in sheep. Proceedings of the Nutrition Society of Australia 9, 184.

Masters, D. G. \& Fels, H. E. (1980). Effect of zinc supplementation on the reproductive performance of grazing Merino ewes. Biological Trace Element Research 2, 281-290.

Masters, D. G. \& Somers, M. (1980). Zinc status of grazing sheep: seasonal changes in zinc concentrations in plasma, wool and pasture. Australian Journal of Experimental Agriculture and Animal Husbandry 20, 20-24.

Masters, D. G., Chapman, R. E. \& Vaughan, J. D. (1985). Effects of zinc deficiency on the wool growth, skin and wool follicles of pre-ruminant lambs. Australian Journal of Biological Science 38, 255-264.

Mills, C. F., Dalgarno, A. C., Williams, R. B. \& Quarterman, J. (1967). Zinc deficiency and the zinc requirements of calves and lambs. British Journal of Nutrition 21, 751-768.

Minson, D. J. (1990). Forage in Ruminant Nutrition, p. 12. New York: Academic Press.

Nagorcka, B. N. (1979). The effect of photoperiod on wool growth. In Physiological and Environmental Limitations to Wool Growth, pp. 127-137 [J. L. Black and P. J. Reis, editors]. Armidale: University of New England Publishing Unit. 
National Health and Medical Research Council (1985). Code of Practice for the Care and Use of Animals for Experimental Purposes, by the National Health and Medical Research Council, Commonwealth Scientific and Industrial Research Organisation and the Australian Agricultural Council. Canberra: Australian Government Publishing Service.

Neathery, M. W., Rachmat, S., Miller, W. J., Gentry, R. P. \& Blackmon, D. M. (1972). Effect of chemical form of orally administered ${ }^{65} \mathrm{Zn}$ on absorption and metabolism in cattle. Proceedings of the Society for Experimental Biology and Medicine 139, 953-956.

Ott, E. A., Smith, W. H., Stob, M. \& Beeson, W. M. (1964). Zinc deficiency syndrome in the young lamb. Journal of Nutrition 82, 41-50.

Ott, E. A., Smith, W. H., Stob, M., Parker, H. E., Harrington, R. B. \& Beeson, W. M. (1965). Zinc requirement of the growing lamb fed a purified diet. Journal of Nutrition 87, 459-463.

Standing Committee on Agriculture (1990). Feeding Standards for Australian Livestock. Ruminants. Melbourne: CSIRO, Australia.

Steel, R. G. D. \& Torrie, J. H. (1980). Principles and Procedures of Statistics, a Biometrical Approach, 2nd ed. Singapore: McGraw-Hill Company.

Suttle, N. F., Lloyd-Davies, H. \& Field, A. C. (1982). A model for zinc metabolism in sheep given a diet of hay. British Journal of Nutrition 47, 105-112.

Ulrich, A. (1952). Physiological bases for assessing the nutritional requirements of plants. Anmual Review of Plant Physiology 3, 207-228.

Underwood, E. J. \& Somers, M. (1969). Studies of zinc nutrition in sheep. I. The relation of zinc to growth, testicular development and spermatogenesis in young rams. Australian Journal of Agricultural Research 20, 889-897.

Vallee, B. L. \& Falchuk, K. H. (1981). Zinc and gene expression. Philosophical Transactions of the Royal Society B 294, 185-197.

White, C. L., Chandler, B. S. \& Peter, D. W. (1991). Zinc supplementation of lactating ewes and weaned lambs grazing improved Mediterranean pastures. Australian Journal of Experimental Agriculture 31, 183-189. 